\title{
Introgression between Apis mellifera capensis Escholtz and Apis mellifera scutellata Lepeletier: the sting pheromones
}

\author{
HR Hepburn 1, GE Jones 1, R Kirby ${ }^{2}$ \\ 1 Department of Zoology and Entomology; \\ 2 Department of Biochemistry and Microbiology, Rhodes University, Grahamstown, 6140 South Africa
}

(Received 10 February 1994; accepted 25 June 1994)

\begin{abstract}
Summary - The 8 principal components of the alarm pheromone from the stings of guard bees from natural populations of Apis mellifera capensis and $A m$ scutellata and areas of hybridization were analysed by gas chromatography. $A m$ scutellata produces significantly more secretion than $A m$ capensis. Autocorrelation analyses of intercolonical variance indicates regions of significant variation in these traits. This introgression coincides with hybridization zones previously defined by other variables. Introgression intensity is related to relative honeybee population density and reveals a probable cyclical bottleneck in 1 area generated by climatic oscillations.
\end{abstract}

\section{Apis mellifera capensis / Apis mellifera scutellata / hybridization / sting pheromone}

\section{INTRODUCTION}

Coincident, but not concordant, zones of natural hybridization between Apis mellifera capensis and $A m$ scutellata emerged from analyses of their reproductive biology (Hepburn and Crewe, 1991), morphometry (Crewe et al, 1994) and mtDNA haplotypes (Moritz et al, 1994). Thus, additional probes were sought to further define the structure of these populations and the intensity and direction of gene flow between them. Capensis is extremely docile and scutellata exceptionally aggressive, but the constituents of the sting alarm pheromones of their guard bees do not differ (Blum and Fales, 1988).

For other honeybees, the intercolonial variance for these same pheromones was significantly greater in hybrids of landrace crosses (Boch and Rothenbuhler, 1974) or between races of honeybees (Collins et al, 1989). Moreover, the constituents of the pheromonal bouquet are highly genetically correlated, their heritabilities approach unity (Collins et al, 1987) and gentleness may be dominant over aggressiveness (Kerr et al, 1967; Boch and Rothenbuhler, 1974). Thus we measured the variance in alarm pheromone production from the stings of 
guard bees on 3 regional transects to assess the introgression of this trait in the natural hybridization process between capensis and scutellata.

\section{MATERIALS AND METHODS}

Worker honeybees were collected from 258 colonies from 29 western, 11 central and 16 eastern localities in the Cape Province. Because capensis and scutellata are separated on a north-south axis these 3 regions represent the east-west limits and the midpoint of the distribution of these races (fig 1; Hepburn and Crewe, 1991). The distances between localities within each region averaged about $50 \mathrm{~km}$ (fig 1). To eliminate age effects, stings from 6 guard bees (assumed to be at least 2 weeks old; Whiffler et al, 1988) from each of 4-5 colonies per locality were removed and stored in dichloromethane for gas chromatographic analysis. The samples were measured with a Hewlett-Packard 5890 Series II gas chromatograph fitted with a bonded methyl silicone fused silica capillary column $(0.3 \mathrm{~mm} \times 25$ $\mathrm{m})$, using $n$-tetradecane as an internal standard. Compounds were quantified with an HP 3396 Series II integrator calibrated against authentic standards of sting pheromone constituents.

Means and standard deviations for each of 8 pheromonal constituents (isopentyl alcohol, $n$ butyl acetate, isopentyl acetate, benzyl alcohol, $n$ octyl acetate, 2-nonanol, benzyl acetate and $n$ decyl acetate) were used to obtain intercolonia variance for each locality. Separate comparisons were then made for locality variances for each of the 3 separate (west, central, and east in figure 1) regions. Finally, localities were grouped in log classes to define areas within each of the 3 main regions to reflect the intensity of variation for each region ( $c f$, fig 2). In addition, the complete data set was subjected to a 2-dimensional spatial autocorrelation analysis (Oden and Sokal, 1986) and individual correlograms were obtained for each of the 8 constituents of the sting pheromone. The data were also subjected to a principal compo-

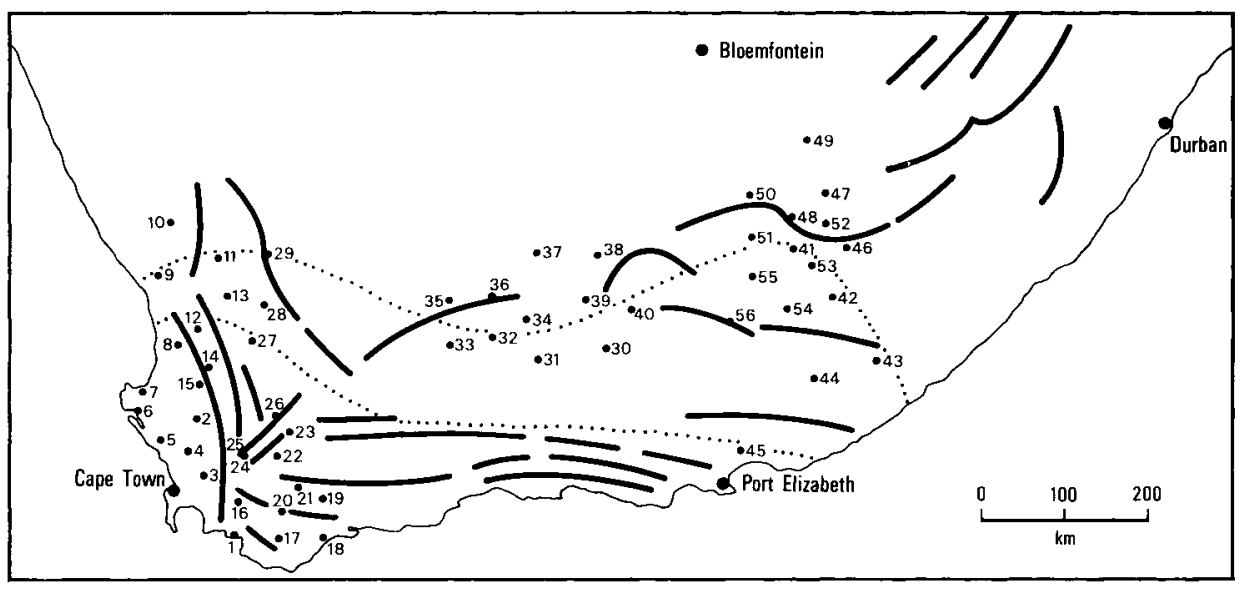

Fig 1. Map of southern Africa showing the localities sampled. Major mountain ranges are indicated as solid stripes. Biologically defined distributions of the 'pure' races are indicated by dotted lines, capensis below the lower line and scutellata above the upper line, the hybrid zone is the area between the 2 lines (Hepburn and Crewe, 1991). 1. Hermanus, 2. Somerset West, 3. Paarl, 4. Malmesbury, 5. Darling, 6. Langebaan, 7. Laaiplek, 8. Elandsbaai, 9. Lutzville, 10. Bitterfontein, 11. Nieuwoudtville, 12. Clanwilliam, 13. Botterkloof, 14. Citrusdal, 15. Piketberg, 16. Villiersdorp, 17. Napier, 18. Skipskop, 19. Swellendam, 20. Riviersonderend, 21. Bonnievale, 22. Sandvlei, 23. Touwsrivier, 24. Worcester, 25. Ceres, 26. Tweerivier, 27. Elandsvlei, 28. Sonop, 29. Calvinia, 30. Aberdeen, 31. Wiegenaarspoort, 32. Beaufort West, 33. Middelwater, 34. Nelspoort, 35. Rietfontein, 36. Booiskraal, 37. Victoria West, 38. Richmond, 39. Murraysburg, 40. Boesmanskop, 41. Molteno, 42. Queenstown, 43. Stutterheim, 44. Fort Beaufort 45. Addo, 46. Dordrecht, 47. Aliwal North, 48. Burgersdorp, 49. Smithfield, 50. Venterstad, 51. Steynsburg, 52. Jamestown, 53. Sterkstroom, 54. Tarkastad, 55. Hofmeyr, 56. Cradock. 


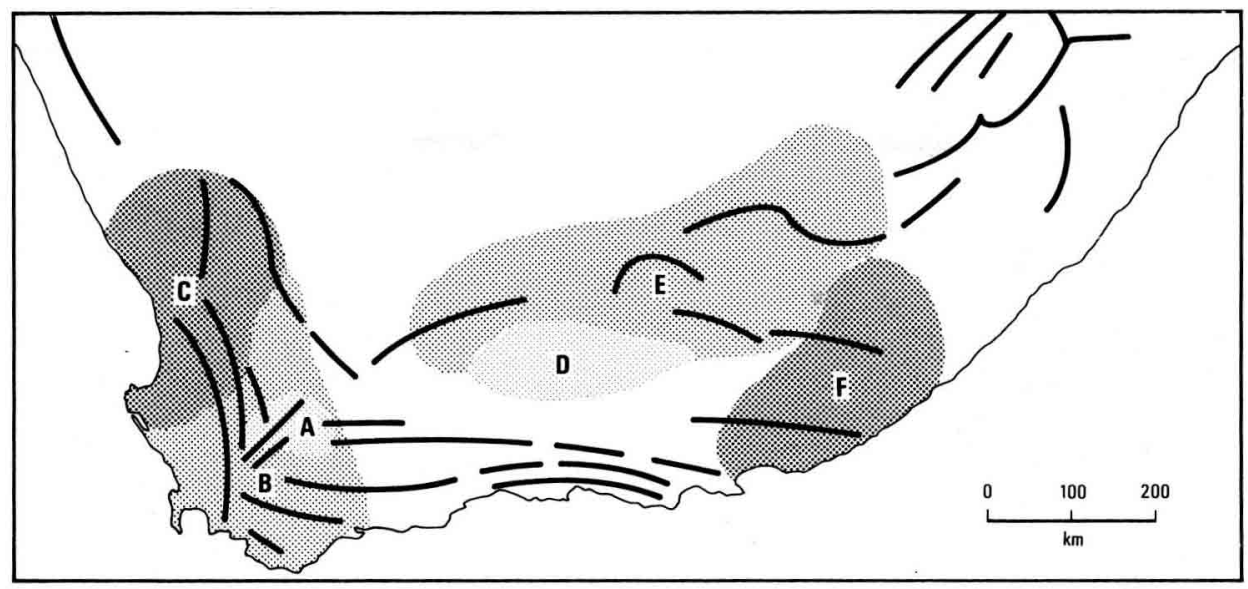

Fig 2. Zones of sting pheromone variance in southern Africa plotted by log-transforming the real variance (table I) and grouping data in 3 log classes: highest variance $(0-2)=$ darkest tone; medium variance $(2-4)=$ medium tone; least variance $(4-6)=$ lightest tone. Letters refer to the groups of localities indicated in table $\mathrm{I}$.

nents analysis to assess whether the total locality data formed a single (1 population) or a group ( 2 or more populations) of clusters.

Relative honeybee colony population density was estimated indirectly by beekeeper density for each region. There has never been any traditional beekeeping south of the Limpopo River and bees are almost only kept by descendants of immigrants from Europe. Aside from large cities, which are artificial oases, the density of beekeepers reflects the general agricultural carrying capacity of the land. The client data base $(n=4000)$ of the largest national supplier of beekeeping equipment was used to plot beekeeper density per map grid square (about $10000 \mathrm{~km}^{2}$ ). The difficulty of locating beekeepers in each hinterland locality during 8 years of field work provided additional confidence as to the usefulness of the commercial data base. Thus, only relative differences are suggested, not real colonies $/ \mathrm{km}^{2}$, which we cannot yet estimate.

\section{RESULTS}

The sting pheromones measured in this study are from honeybees from areas that yield 2 distinct clusters (the races capensis and scutellata) on morphometric analysis but their hybrids yield a single diffuse cluster (Crewe et al, 1994). When the alarm pheromones of the sting were analyzed by principal components analysis only a single cluster was obtained. Thus capensis and scutellata resolve into a single large, continuous and highly variable population for this trait. Nonetheless, there was a highly significant difference $(P<0.01)$ for the total amount of sting pheromone produced by guard bees from biologically defined areas (fig 1) for pure capensis (0.06 $\mu \mathrm{g} / \mathrm{bee})$ and scutellata $(0.20 \mu \mathrm{g} / \mathrm{bee})$; the latter produces 3 times more sting pheromone than the former (this data set is not directly relevant to introgression but is available on request).

There were order of magnitude differences of variance in the total pheromonal bouquet as well as for each of the individual constituents between groups of localities (table I). In the 2-dimensional spatial autocorrelation analyses the mean values of the pheromones yielded a north-south inclined 
Table I. Intercolonial variances $\left(\times 10^{3}\right)$ of sting alarm pheromones for localities shown in figure 1.

Locality Isopentyl n-Butyl Isopentyl Benzyl n-Octyl 2-Nonanol Benzyl n-Decyl Mean and alcohol acetate acetate alcohol acetate area * acetate acetate variance pheromones

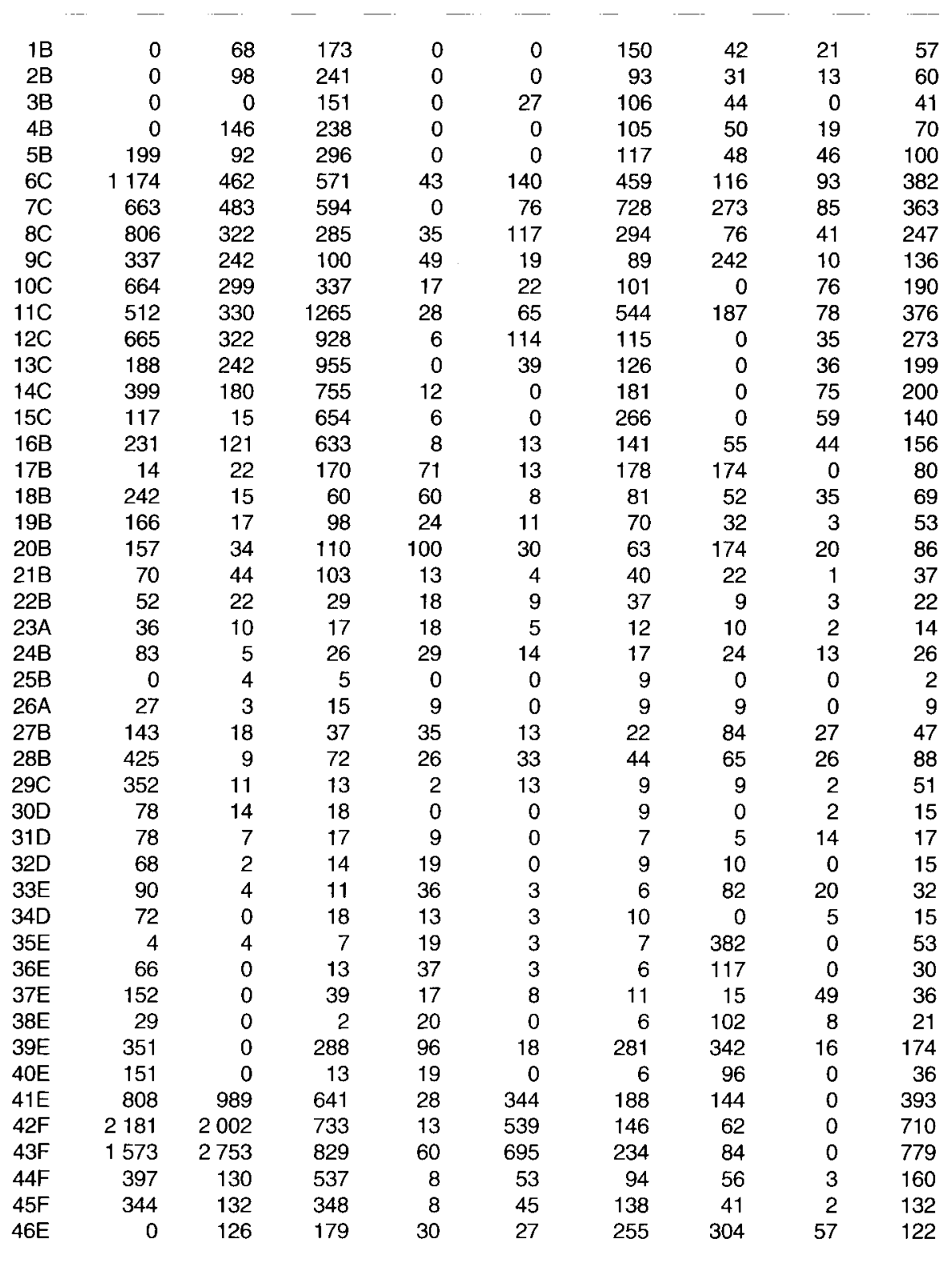


Table I. Cont.

\begin{tabular}{|c|c|c|c|c|c|c|c|c|c|}
\hline $\begin{array}{c}\text { Locality } \\
\text { and } \\
\text { area }^{*}\end{array}$ & $\begin{array}{l}\text { Isopentyl } \\
\text { alcohol }\end{array}$ & $\begin{array}{l}\mathbf{n} \text {-Butyl } \\
\text { acetate }\end{array}$ & $\begin{array}{l}\text { Isopentyl } \\
\text { acetate }\end{array}$ & $\begin{array}{l}\text { Benzyl } \\
\text { alcohol }\end{array}$ & $\begin{array}{l}\mathrm{n} \text {-Octy } \\
\text { acetate }\end{array}$ & 2-Nonanol & $\begin{array}{l}\text { Benzyl } \\
\text { acetate }\end{array}$ & $\begin{array}{l}\mathrm{n} \text {-Decyl } \\
\text { acetate }\end{array}$ & $\begin{array}{c}\text { Mean } \\
\text { variance } \\
\text { of } 8 \\
\text { oheromones }\end{array}$ \\
\hline $47 \mathrm{E}$ & 147 & 125 & 235 & 11 & 56 & 122 & 54 & 18 & 96 \\
\hline $48 \mathrm{E}$ & 98 & 53 & 153 & 2 & 10 & 61 & 16 & 9 & 50 \\
\hline $49 \mathrm{E}$ & 31 & 35 & 257 & 4 & 4 & 124 & 35 & 10 & 63 \\
\hline $50 E$ & 85 & 24 & 68 & 4 & 0 & 69 & 23 & 12 & 36 \\
\hline $51 \mathrm{E}$ & 0 & 45 & 99 & 10 & 0 & 80 & 40 & 7 & 35 \\
\hline $52 \mathrm{E}$ & 82 & 109 & 138 & 6 & 33 & 109 & 62 & 16 & 69 \\
\hline $53 \mathrm{E}$ & 85 & 71 & 145 & 6 & 39 & 174 & 37 & 12 & 71 \\
\hline $54 \mathrm{E}$ & 72 & 77 & 159 & 1 & 40 & 95 & 26 & 10 & 60 \\
\hline $55 \mathrm{E}$ & 59 & 84 & 172 & 3 & 30 & 138 & 46 & 9 & 68 \\
\hline $56 \mathrm{E}$ & 77 & 77 & 188 & 0 & 53 & 77 & 21 & 9 & 63 \\
\hline
\end{tabular}

plane. This form of analysis does not directly yield map coordinates but gives information on the compass direction of trends in the data. The mean variance values of the pheromones gave a minimum autocorrelation in the central region of the correlogram and maximum values to the north and south (ie a saddle, cf Oden and Sokal, 1986). Individual pheromone levels and variances for all 8 constituents were significantly autocorrelated.

The geographic distribution of the total variance of the sting pheromones is more readily visualised as areas within regions based on their log-transform values (fig 2) than in the actual correlograms. Introgression intensity is equally high on the west and east sides of the country but is only moderate in the central region. Estimates of probable relative population density for honeybee colonies are given in log-transform classes in figure 3 . In general the higher levels of introgression for the sting pheromones occur in those areas of higher relative honeybee population density in the eastern and western regions (compare figs 2 and 3 ).

\section{DISCUSSION}

In the present study we found that the guard bees of capensis produced significantly less sting pheromone than those of scutellata for groups of guard bees taken from biologically defined areas of the pure races. Similarly, the variances for both groups of pure race samples (within populations) were significantly lower than those for bees identified biologically and morphometrically as hybrids (between populations). Because the heritabilities of the sting pheromones are close to 1 (Collins et al, 1987), a large part of the variability assigned to hybrid bees must arise through introgression. This interpretation for natural populations is supported by the heterozygosity obtained from landrace crosses (Boch and Rothenbuhler, 1974) and interracial hybrids (Collins et al, 1989). 


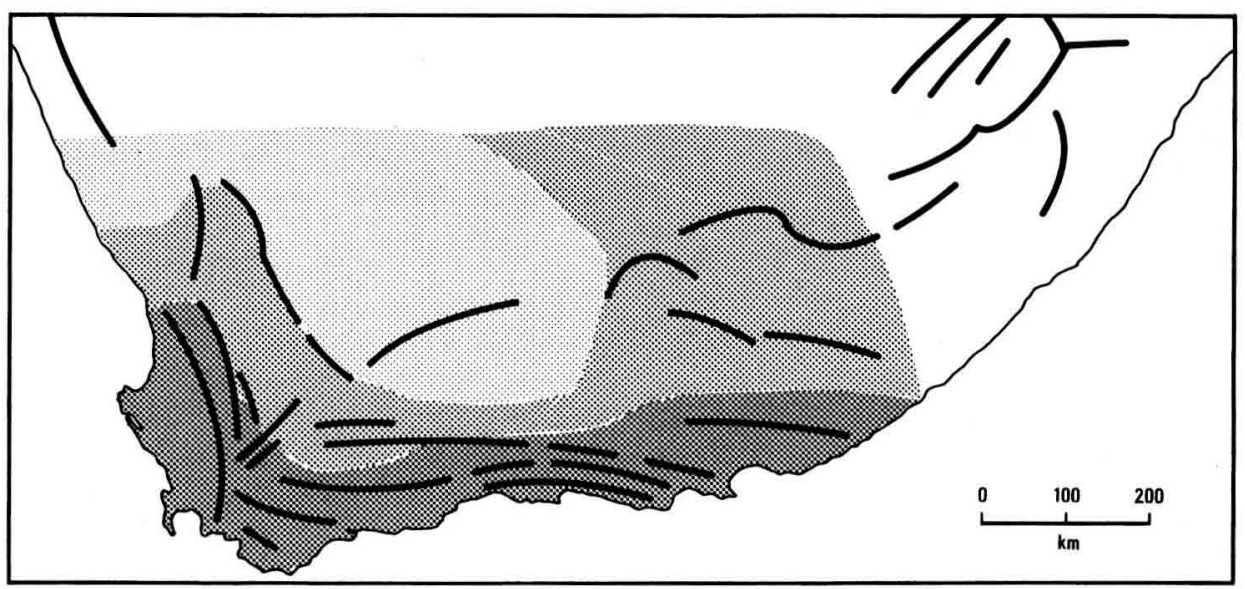

Fig 3. Estimated honeybee colony population density distribution for southern Africa. Zones were plotted by log-transforming known beekeeper density to obtain an index of relative difference. Increasing shade tone density indicates increasing bee colony population density: lightest tone $=$ log classes $0-2 ;$ medium tone $=\log$ classes $2-4$; darkest tone $=\log$ classes $4-6$.

The dynamics of the introgression for sting pheromones and probable direction of flow can be inferred from a consideration of the introgression of other traits in relation to honeybee population density, topography and climatic cycles. Comparisons of figures 2 and 3 show that the population density of honeybee colonies gradually decreases from south to north for the area considered and so too must the probability of opportunities for gene flow. The direction of gene flow is indicated indirectly by the intensity of variance values spreading in broad heads from capensis areas into scutellata areas, particularly to the west and east. That the converse is not the dominant direction of flow is supported by other evidence below.

Figure 4 shows the limits of known introgression for several very different capensis traits. The mitochondrial DNA haplotype, PoQQa is fixed in capensis and occurs with a $100 \%$ frequency to the line drawn and extends another $1000 \mathrm{~km}$ north with gradually decreasing frequency (Moritz et al, 1994). It may be that mtDNA can introgress further than nuclear DNA because of the capensis gene for diploid eggs laid by workers. The limits for the expression of the latter trait are south of the haplotype line as are those obtained from morphometric analyses for hybrids (fig 4). Lastly, continuous qualitative assessments of colony temperament in the field indicated that truly fierce and aggressive bees (a scutellata trait) only occur above the northern line limit for the trait 'diploid eggs laid by workers'. Since docility in bees (a capensis trait) is probably genetically dominant over aggressiveness (Kerr et al, 1967; Boch and Rothenbuhler, 1974) this further suggests gene flow to the north from capensis to scutellata areas.

Collectively, the data of figure 4 yield broad bands in which a differential introgression of traits between capensis and scutellata occurs, the dominant (but not the only) direction being from the south. The intensity of introgression is related to apparent honeybee population density and is 


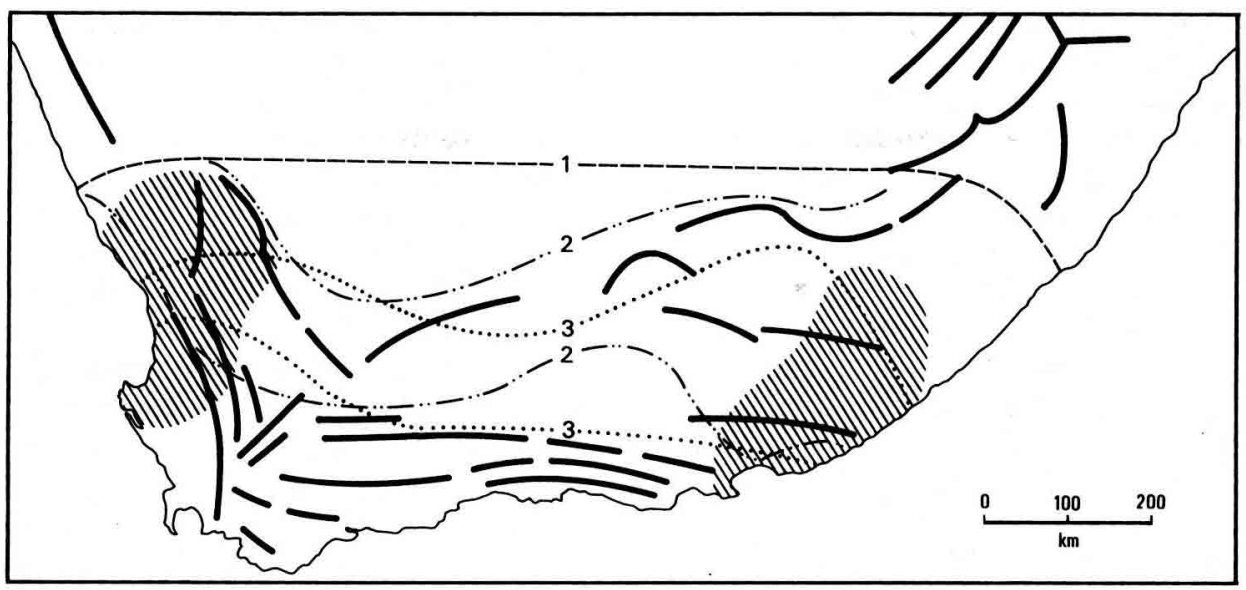

Fig 4. Boundaries for the occurrence of $A m$ capensis $\times A m$ scutellata hybrid traits. Line $1=$ northern limit of $100 \%$ frequency of the capensis haplotype PoQQa (Moritz et al, 1994); line 2 = morphometrically defined intermediate zone (Crewe et al, 1994); line $3=$ area for expression of both haploid and diploid eggs of laying workers (Hepburn and Crewe, 1991); hatched areas to west and east = maximum variance of sting pheromones (fig 2).

sharply defined by the variance values of the sting pheromones. These bands of introgression probably oscillate geographically with alternating decades of severe drought and somewhat wetter years in the Karoo (Tyson, 1986). The reduced population density particularly marked in the central Cape is best interpreted as a classical bottleneck leading to reduced genetic variability in this area.

Superimposed on these cycles are temperate winters to the south (seaside of the mountains) during which capensis migrates/absconds; and, more severe weather to the north (great interior highveld) were scutellata does not move (Hepburn and Crewe, 1991). Capensis also has metabolic, thermoregulatory and reproductive advantages over scutellata (Hepburn et al, 1993; Hepburn and Allsopp, 1994). In conclusion, the sting pheromone measurements show that this trait is an extremely useful probe for measuring introgression in natural populations of honey- bees. Introgression for this trait between capensis and scutellata reaches maximum intensity within a broad band of other traits previously measured for these 2 races (fig 4).

\section{ACKNOWLEDGMENTS}

We thank RFA Moritz for comment and DJ Hepburn for collecting the bee material.

\footnotetext{
Résumé - Introgression entre Apis mellifera capensis Escholtz et Apis mellifera scutellata Lepeletier : les phéromones d'alarme de l'aiguillon. Les zones d'hybridation entre $A m$ capensis et $A m$ scutellata coincident mais ne concordent pas avec les paramètres biologiques et morphologiques. Parce que les phéromones de l'aiguillon présentent une forte héritabilité, nous avons étudié leur production dans 258 colonies réparties en 56 localités d'Afrique du
} 
Sud (fig 1). Nous avons mesuré par chromatographie en phase gazeuse les $8 \mathrm{com}$ posés principaux (tableau I) des phéromones de l'aiguillon d'abeilles gardiennes provenant de populations naturelles d' $A m$ capensis et d'A $m$ scutellata et de populations situées le long de 3 transects d'hybridation. La densité relative des populations d'abeilles a été estimée indirectement d'après la densité des apiculteurs (fig 3 ). Les écarts types de chaque composé phéromonal ont été additionnés pour obtenir les valeurs de la variance inter-colonies par localité, puis regroupés en zones au sein de chacune des 3 régions (tableau I, figs 1 et 2). Les données ont subi ensuite une analyse d'autocorrélation spatiale à 2 dimensions pour déterminer la direction probable du flux génique et l'intensité des variations entre $A m$ capensis et $A m$ scutellata pour chacune des régions étudiées (fig 1). Les corrélogrammes résultants ont été visualisés géographiquement par une transformation logarithmique de la variance (fig 2). $A m$ scutellata produit 3 fois plus de phéromone de l'aiguillon qu'A $m$ capensis. L'hybridation est estimée en termes de variance qui diffère d'un ordre de grandeur d'une population à l'autre. L'introgression a la même intensité dans les régions orientale et occidentale mais est plus faible dans la région centrale (fig 2). Ceci correspond tout à fait avec la densité relative des colonies (fig 3 ). Ces régions d'introgression intense en ce qui concerne les phéromones de l'aiguillon coïncident avec la répartition du caractère hybride «œufs haploïdes et diploïdes pondus par les ouvrières» et des hybrides définis du point de vue morphologique (fig 4). On en conclut que la position géographique des diverses bandes d'introgression varie selon les décennies en fonction du changement climatique cyclique qui affecte la densité de population.

\section{$A$ capensis / $A$ m scutellata / hybrida- tion / phéromone alarme}

Zusammenfassung - Überlappung zwischen Apis mellifera capensis Escholtz und Apis mellifera scutellata Lepeletier: die Alarmpheromone. Die Zonen der Hybridisierung zwischen $A$ m capensis und A $m$ scutellata stimmen bezüglich biologischer und morphologischer Parameter nicht überein. Wegen der hohen Heritabilität der Zusammensetzung der Alarmpheromone des Stachels wurde dieses Merkmal bei 258 Völkern an 56 verschiedenen Orten in Süd Afrika untersucht (Abb 1). Die 8 Hauptkomponenten (Tabelle I) der Alarmpheromone der Wächterbienen in natürlichen Populationen von $A m$ capensis und $A m$ scutellata wurden entlang von 3 Schnittlinien über die Hybridisierungszone gaschromatographisch gemessen. Die relative Dichte der Bienenpopulation wurde indirekt durch die Dichte der Imker bestimmt (Abb 3). Die Standardabweichung für jede Pheromonkomponente wurde zusammengefaßt, um die Varianz der Werte pro Volk und Ort zu bestimmen und danach in Grupenareale für jede der 3 Regionen eingeordnet (Tabelle I, Abb 1,2). Die Daten wurden einer zweidimensionalen räumlichen Autokorrelationsanalyse unterzogen, um die wahrscheinliche Richtung des Genflusses und die Größe der Variation zwischen $A$ $m$ capensis und $A m$ scutellata für alle 3 untersuchten Regionen zu bestimmen (Abb 1). Die Korrelogramme wurden geographisch dargestellt, indem die Varianzen an den entsprechenden Positionen eingetragen wurden (Abb 2). A $m$ scutellata produzierte 3 mal soviel Alarmpheromon wie $A$ $m$ capensis. Die Hybridisierung wurde in Form der Varianzen bestimmt, die sich innerhalb der Populationen um eine Grössenordnung unterschieden. Die Stärke der Überlappung war in den westlichen und östlichen Arealen gleich hoch, aber schwächer in der zentralen Kapregion (Abb 2). Diese Verteilung stimmt mit der relativen Populationsdichte der Völker überein (Abb 3). Die Areale mit starker Überlappung der Alarm- 
pheromone stimmen mit der Verteilung für das Hybridmerkmal 'haploide und diploide Arbeiterinneneier' und für die morphometrische bestimmten Hybriden überein ( $A b b$ 4). Aus diesen Ergebnissen wird geschlossen, daß die geographische Lage der verschiedenen, Überlappungszonen über Jahrzehnte in Abhängigkeit von zyklischen, die Populationsdichte beeinflussenden Änderungen im Klima schwankt.

\section{A m capensis / A m scutellata / Hybridi- sierung / Alarmpheromon}

\section{REFERENCES}

Boch R, Rothenbuhler WC (1974) Defensive behaviour and production of alarm pheromones in honeybees. $J$ Apic Res 13, 217-221

Blum MS, Fales HM (1988) Chemical releasers of alarm behaviour in the honey bee: informational 'plethora' of the sting apparatus signal. In: Africanized Honey Bees and Bee Mites (GR Needham, RE Page, M Delfinado-Baker, CE Bowman, eds) Ellis Horwood, Chichester, UK, 141-148

Collins AM, Brown MA, Rinderer TE, Harbo JR, Tucker KW (1987) Heritabilities of honey-bee alarm pheromone production. J Hered 78, 29-31
Collins AM, Rinderer TE, Daly HV, Harbo JR (1989) Alarm pheromone production by two honeybee (Apis mellifera) types. J Chem Ecol 15, 1747-1756

Crewe RM, Hepburn HR, Moritz RFA (1994) Morphometric analysis of two southern African races of honeybee. Apidologie 25, 61-70

Hepburn HR, Allsopp MH (1994) Reproductive conflict between honeybees: usurpation of Apis mellifera scutellata colonies by Apis mellifera capensis. S Afr J Sci 90, 247-249

Hepburn HR, Crewe RM (1991) Portrait of the Cape honeybee, Apis mellifera capensis. Apidologie 22, $567-580$

Hepburn HR, Villet MH, Jones GE, Carter AR, Simon U, Coetzer W (1993) Winter absconding as a dispersal mechanism of the Cape honeybee. S Afr J Sci 89 , 294-297

Kerr WE, Goncalves L, Stort C, Bueno D (1967) Biological and genetical information on Apis mellifera adasonii. XXI Int Beekeep Congr p 425

Moritz RFA, Cornuet JM, Kryger P, Garnery L, Hepburn HR (1994) Mitochondrial DNA variability in South African honeybees (Apis mellifera L). Apidologie 25, 169-178

Oden NL, Sokal RR (1986) Directional autocorrelation: an extension of spatical correlograms to two dimensions. Syst Zool 35, 608-617

Tyson PD (1986) Climatic Change and Variability in Southern Africa. Oxford, Cape Town, South Africa

Whiffler LA, Drusedau MUH, Crewe RM, Hepburn HR (1988) Defensive behaviour and the division of labour in the African honeybee (Apis mellifera scutellata). $J$ Comp Physiol A 163, 401-411 